\title{
Study on the impact of energy and environmental efficiency based on DEA-ENDDF and Tobit model
}

\author{
Xiaonan Qin ${ }^{1}$, Yingchun Wang ${ }^{2}$ \\ ${ }^{1}$ School of management, Tianjin University of Technology, Tianjin 300384, China, xiaonanq163@163.com \\ ${ }^{2}$ School of management, Tianjin University of Technology, Tianjin 300384, China, ycwang@sina.com
}

\begin{abstract}
Based on the resource allocation effect, technological innovation effect and competition effect, this paper takes eight comprehensive areas as decision-making units, uses DEA-ENDDF method under the theoretical framework of total factor production with non-radial distance function, calculates energy and environmental efficiency through NDDF of MaxDEA software, makes hypothesis test, and uses Tobit model to analyze the influencing factors of energy and environmental efficiency, such as transportation foundation, economic structure, technological progress, external dependence, energy endowment, population density and other factors are analyzed by regression analysis. Finally, the conclusion is given, in order to explore useful conclusions and explore new ways of energy conservation and emission reduction.
\end{abstract}

\section{Introduction}

Along with the economic development and the continuous increase of GDP, China's economy has made brilliant achievements. The current experience of world economic development shows that the sustainable development of economy and the optimization of ecological environment have become an important symbol to measure the high-quality development of a region. Energy provides inexhaustible power for China's economic achievements, but there are two sides to everything, and the problem of resources and environment is becoming increasingly serious. General Secretary Xi's green development concept of "green water and green mountains are golden mountains and silver mountains" profoundly reveals the extreme importance of ecological environment ${ }^{[1]}$.

The existing research mainly has the following defects: the object is not comprehensive, the generalization is not comprehensive, the internal detailed rules are ignored, the factors are too single to cover more factors, and the model estimation is biased ${ }^{[2]}$.

In this paper, the DEA model is constructed under the non-radial distance function (NDDF):

$\mathrm{D}\left(\mathrm{K}, \mathrm{L}, \mathrm{E}, \mathrm{Y}_{\mathrm{g}}, \mathrm{Y}_{\mathrm{a} 1}, \mathrm{Y}_{\mathrm{a} 2}\right)=\operatorname{Max} . \omega_{\mathrm{K}} \partial_{\mathrm{K}}+\omega_{\mathrm{L}} \partial_{\mathrm{L}}+\omega_{\mathrm{E}} \partial_{\mathrm{E}}+$ $\omega_{\mathrm{Y}_{\mathrm{g}}} \partial_{\mathrm{Y}_{\mathrm{g}}}+\omega_{\mathrm{Y}_{\mathrm{a} 1}} \partial_{\mathrm{Y}_{\mathrm{a} 1}}+\omega_{\mathrm{Y}_{\mathrm{a} 2}} \partial_{\mathrm{Y}_{\mathrm{a} 2}}$

S.t. $\sum_{\mathrm{n}=1}^{\mathrm{N}} \mathrm{Z}_{\mathrm{n}} \mathrm{K}_{\mathrm{n}} \leq \mathrm{K}, \sum_{\mathrm{n}=1}^{\mathrm{N}} \mathrm{Z}_{\mathrm{N}} \mathrm{L}_{\mathrm{n}} \leq \mathrm{L}$,

$\sum_{\mathrm{n}=1}^{\mathrm{N}} \mathrm{Z}_{\mathrm{N}} \mathrm{E}_{\mathrm{n}} \leq \mathrm{E}-\partial_{\mathrm{E}} \quad \mathrm{f}_{\mathrm{E}}, \quad \sum_{\mathrm{n}=1}^{\mathrm{N}} \mathrm{Z}_{\mathrm{n}} \mathrm{Y}_{\mathrm{gn}} \geq \mathrm{Y}_{\mathrm{g}}+$ $\partial_{Y_{g}} f_{Y_{g}}$,

$\mathrm{Y}_{\mathrm{a} 1 \mathrm{n}}=\mathrm{Y}_{\mathrm{a} 1}-\partial_{\mathrm{Y}_{\mathrm{a} 1}} \mathrm{f}_{\mathrm{Y}_{\mathrm{a} 1}}, \sum_{\mathrm{n}=1}^{\mathrm{N}} \mathrm{Z}_{\mathrm{n}} \mathrm{Y}_{\mathrm{a} 2 \mathrm{n}}=\mathrm{Y}_{\mathrm{b} 2}-\partial_{\mathrm{Y}_{\mathrm{a} 2}} \mathrm{f}_{\mathrm{Ya} 2}$

$\mathrm{Zn} \geq 0, \mathrm{n}=1,2, \ldots, \mathrm{N}$.

$$
\partial_{\mathrm{K}}, \partial_{\mathrm{L}}, \partial_{\mathrm{E}}, \partial_{\mathrm{Y}_{\mathrm{g}}}, \partial_{\mathrm{Y}_{\mathrm{a} 1}}, \partial_{\mathrm{Y}_{\mathrm{a} 2}} \geq 0
$$

The optimal solution of relaxed variable is obtained by solving linear programming in the formula. $\mathrm{An} *=\left(\alpha_{n}{ }^{*}{ }^{\prime}, \alpha_{L}^{*}, \alpha_{n}{ }^{*}, \alpha_{n}{ }^{*}{ }_{Y_{g}}, \alpha_{n}{ }^{*}{ }_{Y_{a 1}}, \alpha_{n}{ }_{Y_{a 2}}\right)$.

The total factor environmental efficiency $\left(E_{E E I_{n}}\right)$ of three input factors (labor, capital and energy), one expected output (real GDP) and two unexpected outputs (industrial waste gas emission and industrial waste water emission) is calculated by ENDDF method:

$$
\begin{aligned}
& \mathrm{EEEI}_{\mathrm{n}}=\frac{1}{3}\left[\frac{\frac{Y_{g n}}{E_{n}}}{\frac{\left(Y_{g n}+\alpha_{n}{ }^{*}{ }_{g}\right)}{\left(E_{n}-\alpha_{n}{ }^{*}{ }^{E}{ }^{\left.E_{n}\right)}\right.}}+\frac{\frac{Y_{g n}}{Y_{a 1 n}}}{\frac{\left(Y_{g n}+\alpha_{n}{ }^{*} Y_{g}\right)}{\left(Y_{a 1 n}-\alpha_{n}{ }^{*}{ }_{a 1} Y_{a 1 n}\right)}}+\right.
\end{aligned}
$$

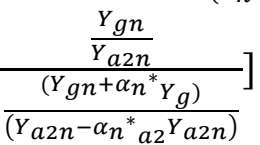

$$
\begin{aligned}
& =\frac{1}{3}\left[\frac{\left(1-\alpha_{\mathrm{n}}{ }^{*} \mathrm{E}\right)+\left(1-\alpha_{\mathrm{n}}{ }^{*} \mathrm{Ya}_{1}\right)+\left(1-\alpha_{\mathrm{n}}{ }^{*} \mathrm{Ya}\right)}{1+\alpha^{*} \mathrm{Y}_{\mathrm{g}}}\right] \\
& =\frac{1-\frac{1}{3}\left(\alpha_{n}{ }^{*} K+\alpha^{*}{ }_{L}+\alpha_{n}{ }^{*}{ }^{*}+\alpha_{n}{ }^{*} Y_{a 1}+\alpha_{n}{ }^{*} Y_{a 2}\right)}{\left.1+\alpha_{n}{ }^{*}{ }_{\mathrm{Yg}}\right)} \text {, } \\
& \mathrm{n}=1,2,3, \ldots, \mathrm{N}
\end{aligned}
$$

$\mathrm{EEI}_{\mathrm{n}}$ reflects the energy and environmental efficiency, and the value is between 0 and 1 . The larger the value is, the higher the energy and environmental efficiency is. When the value is 1 , it means that the decision-making unit is in the frontier of production, and the relative efficiency reaches the optimal level.

\section{Data and empirical analysis}

The data in this paper comes from China energy statistical yearbook and other statistical yearbooks.

This paper uses the panel data of actual GDP, exhaust emissions, energy consumption, labor force and capital stock in eight comprehensive areas of 1995-2018 years in mainland China, and constructs eight provinces as the 
decision-making units to construct the best production boundaries of China's provinces in each period. First, the energy and environmental efficiency (EEEI) is calculated by using the NDDF method of MAXDEA software ${ }^{[3]}$. And the processing summary is shown in Table 1.

Table 1. Calculation Results

\begin{tabular}{|c|c|c|c|c|c|c|}
\hline region & $\begin{array}{c}1995- \\
1999 \\
\end{array}$ & $\begin{array}{c}2000- \\
2004 \\
\end{array}$ & $\begin{array}{l}2005- \\
2009 \\
\end{array}$ & $\begin{array}{l}2020- \\
2014 \\
\end{array}$ & $\begin{array}{l}2015- \\
2018 \\
\end{array}$ & $\begin{array}{c}\text { general } \\
\text { trend }\end{array}$ \\
\hline $\begin{array}{l}\text { Northern coastal } \\
\text { complex }\end{array}$ & 1.00 & 1.00 & 1.00 & 1.00 & 1.00 & c-c-c-c \\
\hline $\begin{array}{l}\text { Comprehensive area in } \\
\text { the middle reaches of } \\
\text { the Yellow River }\end{array}$ & 0.93 & 0.72 & 0.78 & 0.75 & 0.73 & d-i-d-d \\
\hline $\begin{array}{c}\text { Northeast } \\
\text { comprehensive region }\end{array}$ & 0.90 & 0.94 & 0.98 & 1.00 & 1.00 & $\mathrm{i}-\mathrm{i}-\mathrm{i}-\mathrm{c}$ \\
\hline $\begin{array}{c}\text { Eastern coastal } \\
\text { comprehensive area }\end{array}$ & 0.93 & 1.00 & 1.00 & 0.97 & 1.00 & i-c-d-i \\
\hline $\begin{array}{l}\text { Comprehensive area in } \\
\text { the middle reaches of } \\
\text { the Yangtze River }\end{array}$ & 0.95 & 0.85 & 0.86 & 0.88 & 0.87 & $d-i-i-d$ \\
\hline $\begin{array}{l}\text { Southern coastal } \\
\text { complex }\end{array}$ & 1.00 & 1.00 & 1.00 & 1.00 & 1.00 & $\mathrm{c}-\mathrm{c}-\mathrm{c}-\mathrm{c}$ \\
\hline $\begin{array}{c}\text { Southwest } \\
\text { comprehensive region }\end{array}$ & 0.96 & 0.59 & 0.67 & 0.79 & 0.80 & d-i-i-i \\
\hline $\begin{array}{c}\text { Northwest } \\
\text { comprehensive region }\end{array}$ & 0.72 & 0.68 & 0.80 & 0.69 & 0.65 & d-i-d-d \\
\hline National average & 0.93 & 0.85 & 0.89 & 0.89 & 0.88 & d-i-c-c \\
\hline
\end{tabular}

It can be seen from table 1 that the northern coastal comprehensive area and the southern coastal comprehensive area are always on the optimal production boundary, with the best energy and environmental efficiency, while the greater northwest comprehensive area has always been the area with the lowest relative efficiency, which is closely related to the fact that the northwest comprehensive area is the main energy production area in China, and is dominated by traditional coal.

More than half of the comprehensive areas have higher energy and environmental efficiency than the national average level, but the overall number has decreased, reflecting that the differences in energy and environmental efficiency among the comprehensive areas are expanding. The national average energy and environmental efficiency showed a "U-shaped" trend of first decreasing and then increasing, and the five comprehensive areas showed an overall upward trend.

1995-2018 from the fluctuation range of energy and environmental efficiency, we can see that there is an "n-type" trend of expansion, reduction and expansion, in which 1995-2004 is the expansion stage of energy and environmental efficiency, 2005-2011 is the reduction stage of energy and environmental efficiency, and after 2012, the difference of energy and environmental efficiency expands again, but the range of difference narrows.
Table 2. Summary of Hypothesis Test Results

\begin{tabular}{|c|c|c|}
\hline Null hypothesis (H0) & kwallis & p-Value \\
\hline $\begin{array}{c}\text { There is no } \\
\text { significant difference } \\
\text { in energy and } \\
\text { environmental } \\
\text { efficiency among the } \\
\text { comprehensive areas }\end{array}$ & 127.76 & 0.01 \\
& & \\
\hline
\end{tabular}

The results of hypothesis test in Table 2 show that the original hypothesis that there is no significant difference in energy and environmental efficiency among the comprehensive areas is rejected, that is, there is a significant difference in energy and environmental efficiency among the comprehensive areas ${ }^{[4]}$.

\section{Influencing factors and Tobit model}

Because the value of energy and environmental efficiency is between 0-1 (double censored data), and other people's research ${ }^{[5]}$, Tobit model which can deal with the censored data is usually selected to analyze the influencing factors. 
Table 3. Regression Results

\begin{tabular}{|c|c|c|c|c|c|}
\hline variable & $\begin{array}{l}\text { Comprehensive } \\
\text { area in the middle } \\
\text { reaches of the } \\
\text { Yellow River }\end{array}$ & $\begin{array}{l}\text { Northeast } \\
\text { comprehensiv } \\
\text { e region }\end{array}$ & $\begin{array}{l}\text { Eastern } \\
\text { coastal } \\
\text { comprehensiv } \\
\text { e area }\end{array}$ & $\begin{array}{l}\text { Southwest } \\
\text { comprehensive region }\end{array}$ & $\begin{array}{l}\text { Northwest } \\
\text { comprehensive } \\
\text { region }\end{array}$ \\
\hline $\begin{array}{l}\text { Dependence } \\
\text { on foreign } \\
\text { trade }\end{array}$ & $\begin{array}{l}0.338 \\
(15.4) \\
* * *\end{array}$ & $\begin{array}{l}0.073 \\
(7.11) \\
* * *\end{array}$ & $\begin{array}{l}0.888 \\
(3.41) \\
* * *\end{array}$ & $\begin{array}{c}0.127 \\
(11.59) \\
* * *\end{array}$ & $\begin{array}{l}0.203 \\
(11.2) \\
* * *\end{array}$ \\
\hline $\begin{array}{l}\text { Capital per } \\
\text { capita }\end{array}$ & $\begin{array}{l}0.033 \\
(6.27) \\
* * *\end{array}$ & $\begin{array}{l}0.090 \\
(5.68) \\
* * *\end{array}$ & $\begin{array}{c}-0.060 \\
(-2.63) \\
* * *\end{array}$ & $\begin{array}{l}0.065 \\
(8.27) \\
* * *\end{array}$ & $\begin{array}{l}0.284 \\
(11.0) \\
* * *\end{array}$ \\
\hline Tax burden & $\begin{array}{c}-0.26 \\
(-3.75) \\
* * *\end{array}$ & $\begin{array}{c}-0.19 \\
(-2.17) \\
* * *\end{array}$ & $\begin{array}{c}-0.13 \\
(-3.24) \\
* * *\end{array}$ & $\begin{array}{c}-0.90 \\
(-3.23) \\
* * *\end{array}$ & $\begin{array}{l}-0.12 \\
(7.91) \\
* * *\end{array}$ \\
\hline $\begin{array}{l}\text { Industrial } \\
\text { structure }\end{array}$ & $\begin{array}{c}-0.13 \\
(-2.69) \\
* *\end{array}$ & $\begin{array}{l}0.43 \\
(7.39) \\
* * *\end{array}$ & $\begin{array}{c}0.84 \\
(4.31) \\
* * *\end{array}$ & $\begin{array}{c}0.60 \\
(3.71) \\
* * *\end{array}$ & $\begin{array}{c}-0.22 \\
(-4.87) \\
* * *\end{array}$ \\
\hline $\begin{array}{l}\text { Transportati } \\
\text { on } \\
\text { Foundation }\end{array}$ & $\begin{array}{c}0.022 \\
(1.64) \\
* \\
\end{array}$ & $\begin{array}{c}0.047 \\
(1.21) \\
*\end{array}$ & $\begin{array}{l}0.003 \\
(2.02) \\
* *\end{array}$ & $\begin{array}{c}0.045 \\
(1.25) \\
* *\end{array}$ & $\begin{array}{c}0.110 \\
(2.25) \\
* * \\
\end{array}$ \\
\hline $\begin{array}{l}\text { Technical } \\
\text { progress }\end{array}$ & $\begin{array}{l}0.19 \\
(4.64) \\
* * *\end{array}$ & $\begin{array}{c}0.18 \\
(11.4) \\
* * *\end{array}$ & $\begin{array}{l}0.11 \\
(6.9) \\
* * *\end{array}$ & $\begin{array}{c}0.39 \\
(2.56) \\
* * *\end{array}$ & $\begin{array}{c}0.42 \\
(2.82) \\
* * *\end{array}$ \\
\hline $\begin{array}{l}\text { Energy self } \\
\text { sufficiency }\end{array}$ & $\begin{array}{l}0.149 \\
(8.88) \\
* * *\end{array}$ & $\begin{array}{c}0.341 \\
(11.91) \\
* * *\end{array}$ & $\begin{array}{l}0.539 \\
(6.01) \\
* * *\end{array}$ & $\begin{array}{c}0.148 \\
(1.63) \\
* *\end{array}$ & $\begin{array}{l}-0.777 \\
(-8.7) \\
* * *\end{array}$ \\
\hline
\end{tabular}

$$
\begin{aligned}
& \mathrm{Y}^{*}=\mathrm{x} \alpha+\mu, \mu \sim\left(0, \sigma^{2}\right) \\
& \mathrm{Y}=\operatorname{MAX}\left(0, \mathrm{Y} \mathrm{Y}^{*}\right)
\end{aligned}
$$

The assumption of classical linear model obeys normal homovariance, $\mu$ is the value of energy and environmental efficiency, $\mathrm{X}$ is the variable of influencing factors, $\alpha$ is the corresponding influence coefficient.

The influencing factors of energy and environmental efficiency are determined as follows: (1) dependence on foreign trade; (2) per capita capital share; (3) tax burden; (4) industrial structure; (5) transportation base; (6) technological progress; (7) energy self-sufficiency rate (energy production / energy consumption); and (5) industrial structure.

Because the southern coastal comprehensive area and the northern coastal comprehensive area are on the optimal production boundary, this paper only investigates the energy and environmental efficiency of the other six comprehensive areas, using Tobit model regression, and the results are shown in Table $3^{[6]}$.

Foreign trade dependence was positive for all regions.

The per capita capital has a positive impact on the energy and environmental efficiency of the other five comprehensive areas except the eastern coastal comprehensive area, and the comprehensive area in the middle reaches of the Yellow River has the least impact (related to its weak economic foundation) ${ }^{[7]}$.

The tax burden has a negative impact on the energy and environmental efficiency of each comprehensive area.

The industrial structure has a significant negative impact on the energy and environmental efficiency of the comprehensive area in the middle reaches of the Yellow River and Northwest China, and a positive impact on other comprehensive areas.

The impact of transportation infrastructure on energy and environmental efficiency is not significant, but it generally passes the significance test of more than $90 \%$.

Technological progress has a positive impact on the energy and environmental efficiency of each comprehensive area.

The energy self-sufficiency rate has a positive impact on the energy and environmental efficiency of other comprehensive areas except the northwest comprehensive area, and a negative impact on the northwest comprehensive area.

\section{Policy recommendations}

1 We should increase investment, enhance core technology, gradually reduce the proportion of the secondary industry with high energy consumption and high pollution, vigorously develop the tertiary industry, especially the modern service industry, rely on innovation to drive economic development, improve the quality of economic growth, and reduce the pollution content contained in economic output; increase investment in pollution prevention and control technology. Encourage industrial enterprises to develop low-carbon technology and green technology, and promote technological change in the field of energy and environment.

2 Further improve the level of environmental management, strengthen environmental control, formulate more stringent air pollution prevention and control countermeasures and measures, and provide more effective institutional incentives for air pollution 
prevention and control.

3 We will actively promote the conversion project between new and old kinetic energy, and promote industrial transformation and upgrading. Optimize the industrial structure, seize the opportunity, and give full play to the dominant position of enterprises in the transformation process of new and old kinetic energy. Enterprises should strengthen technological innovation, give full play to the role of collaborative innovation between enterprises and universities, actively promote the integrated development of cross-border industries, and promote the development of industries in the direction of green, digital, network and intelligent.

\section{Conclusion}

The results show that the average energy and environmental efficiency of the comprehensive areas in China presents a "U" shape, and most of the comprehensive areas increase in energy and environmental efficiency. The difference of energy and environmental efficiency among the comprehensive areas shows a " $\mathrm{n}$ " shape of expansion narrowing expansion, but the overall gap converges and narrows.

So, We should strive to improve energy and environmental efficiency.

\section{References}

1. Li Yu. Energy economic efficiency, energy environmental performance and regional economic growth [J]. China market, 2020 (23): 28-29

2. Wang Xinyue, sun Ruiyang, Wang Xiaolei, Fu Zheyi. Research on urban energy and environmental efficiency in China [J]. China mining, 2020,29 (07): 28-34

3. Key discipline of environmental and economic policy research center of Ministry of ecological environment: Research on energy, environment and climate change $[\mathrm{J}]$. Environment and sustainable development, 2020,45 (03): 32

4. Energy, environment and climate change [J]. Environment and sustainable development, 2020,45 (03): 163

5. Zhang N, Kong F, Choi Y, Zhou P. The effect of size-control policy on unified energy and carbon efficiency for Chinese fossil fuel power plants. Energy Policy. 2014;70:193-200. doi:10.1016/j.enpol.2014.03.031.

6. Mohapatra Subhashree, Verma Shrey, Chowdhury Subhankar, et al. A critical appraisal of green vegetated roofs: Energy and environment in focus. 2020,

7. Maria Segura, Marianne Clayton, Lara Manuel. State aid rules for environmental purposes: an effective instrument for implementing EU policy priorities? 2020,:1-13. 